\title{
Revolution in the head: A conversation with Paulo Freire
}

\author{
Paul Stanistreet ${ }^{1}$
}

Accepted: 4 October 2021 / Published online: 25 October 2021

(c) UNESCO Institute for Lifelong Learning and Springer Nature B.V. 2021

I began this editorial on 19 September 2021, on a day when educators around the world were celebrating the centenary of Paulo Freire's birth. It is a significant anniversary for scholars of education, as well as for many practitioners and activists, and indeed for all of those working in and around education who see their work as in some way connected to a broader social purpose. Freire's most-read and mostreferenced work, Pedagogy of the Oppressed, published in 1968 in Portuguese and in 1970 in English, is one of the foundational texts of critical pedagogy. His ideas about freedom and liberation, and the relation between reflection and action in education, continue to inspire and provoke 50 years on. And while Freire has been viewed by some as a figure of the past with limited applicability to the challenges of the modern world, the changing nature of these challenges and the growing sense that business as usual is no longer an option, politically, economically and educationally, has prompted a resurgence of interest in his ideas, with new generations of scholars convinced of the importance of resuming the conversation Freire began more than five decades ago.

Freire's celebrated Pedagogy of the Oppressed was first published at a moment of hope and promise, when the possibility of organising society in a different way, centred around values of freedom and social justice, was fleetingly real (or seemed so). By the time the English language edition came out (Freire 1970), ${ }^{1}$ this hope had already begun to dwindle, and in the decades to come it was largely forgotten or, if not forgotten, then dismissed or derided. Human society was remade during this period and education was recast in its image. In a really remarkably short period of time we stopped wondering about how education could help people realise their full potential as citizens and human beings, and focused all the resources of the state on preparing people not for life but merely for work. Neoliberalism reimagined the purposes of education in terms of human capital and individual self-interest, reckoning its value in purely economic terms and its benefits as largely private, not public.

\footnotetext{
1 Freire, P. (1970). Pedagogy of the oppressed. Transl. from Portuguese by Myra Bergman Ramos. New York: Continuum Press.
}

Paul Stanistreet

p.stanistreet@unesco.org

1 UNESCO Institute for Lifelong Learning, Hamburg, Germany 
The pervasive "common sense" that capitalism was the only viable model for our societies not only shut down wider debate about the point and purpose of education, it also made it harder to imagine alternative ways of organising our world, making radical dissent increasingly marginal and inarticulate. The COVID-19 pandemic, combined with the other pressing challenges humanity faces, most notable among them the climate emergency, have again made another world seem possible, or perhaps necessary, throwing the grim inequities of current arrangements and the threadbare nature of the social contract that supports them into sharp relief. The revival of interest in Freire's work can be partly explained by a growing resistance to the depoliticisation of education and the grim instrumentalism of neoliberal conceptions of its purpose and value. But it also suggests a recognition that economic oppression is reflected in every other area of life, including in education, where privilege is confirmed and reproduced, as well as acknowledgement of the contrary: that revolution can start anywhere, including in the hearts and minds of students and teachers.

Such a reappraisal of Freire's work is, therefore, timely. As Henri Giroux (2021) argues, ${ }^{2}$ he deserves better than the self-regarding admiration of individuals and organisations that relish the reflected glory of their association with Freire but in their practice oppose his ideas to the point sometimes of believing the opposite. Freire, Giroux writes, "was a revolutionary whose passion for justice and resistance was matched by his hatred of neoliberal capitalism and loathing for authoritarians of all political stripes. Put simply, he was not merely a public intellectual but also a freedom fighter" (ibid.). He saw education as a political field and teaching as a practice that had freedom, agency and justice as its goals. He contested the supposed neutrality of the education environment, and sought to remake it in terms of critical, contextualised thinking, a focus on collective action and co-production of knowledge, and the cultivation of critical consciousness through struggle. The past decades' emphasis on teaching to the test, rote learning and preparation for a job seems more challengeable and open to serious question than it has been for some time. Freire gives us a language with which to consolidate this challenge and create something different, grounded in dialogue and critical reflection. His radicalism is very much of our time.

I would highlight three aspects of Freire's thought that resonate particularly with the challenges of the moment. First, Freire puts the learner truly at the centre. Governments often express a desire to do this but, in most cases, lack the conviction to do it in a meaningful way. Freire shows us how. He believed that real learning, learning that was "authentic", only really happened when learners were empowered to find solutions to the real-world problems they encountered in their lives. Authentic thinking, he argued, was "thinking that is concerned about reality" (Freire 2005, p. 77; emphasis in original). ${ }^{3}$ Freire recognised the

\footnotetext{
${ }^{2}$ Giroux, H. (2021). Remembering Paulo Freire as a freedom fighter. Counter Punch, 24 September [online article]. Retrieved 29 September 2021 from https:/www.counterpunch.org/2021/09/24/remem bering-paulo-freire-as-a-freedom-fighter/.

3 Freire, P. (2005). Pedagogy of the oppressed. 30th anniversary edn. New York/London: Continuum Press. Retrieved 29 September 2021 from https:/envs.ucsc.edu/internships/internship-readings/freirepedagogy-of-the-oppressed.pdf.
} 
importance of distinctive educational contexts, and understood that learners learn best when they engage with the things that matter to them. However, for the most part, attempts to engage learners are superficial or tokenistic. Freire believed that, to be more than this, they had to begin with reality, but not a reality imposed by teacher "narration". Instead, that reality had to be discovered, constituted and engaged with. Problem-posing education, presupposing a dialogue of acknowledged equals, reconstituted the relationship between teacher and student:

The teacher is no longer merely the-one-who-teaches, but one who is himself taught in dialogue with the students, who in turn while being taught also teach. They become jointly responsible for a process in which all grow. In this process, arguments based on "authority" are no longer valid; in order to function, authority must be on the side of freedom, not against it. Here, no one teaches another, nor is anyone self-taught. Men [sic] teach each other, mediated by the world, by the cognizable objects which in banking education are "owned" by the teacher (ibid., p. 80; emphases in original).

Compared to the "narrative" or "banking" model of education, through which knowledge is deposited in the minds of learners (a "gift" bestowed by the knowledgeable on those who lack knowledge), "problem-posing education involves a constant unveiling of reality. The former attempts to maintain the submersion of consciousness; the latter strives for the emergence of consciousness and critical intervention in reality" (ibid., p. 81; emphases in original).

Second, Freire affirmed the value of informal and non-formal learning. The classroom is not the only environment in which learning can or does take place. It happens at home, in the community and in the workplace. However, it is the way in which it happens that is most important. Freire believed that dialogue was key to learning, and that dialogue had to be premised on respect and co-production of knowledge. If the structure of education did not involve or permit dialogue, if it was in this sense "authoritarian", it should be challenged, he argued. This gives a significant role to informal and non-formal learning, which are typically conversational in nature, less regimented in terms of planning and not reliant on the "narration" of a curriculum. These forms of learning, and adult and popular education more generally, have been embattled in recent decades, with places and spaces in which people can come together to engage in the "practice of freedom" fast disappearing. However, the demand for more creative, critical-minded citizens capable of responding to challenges such as the pandemic, climate change and the spread of disinformation fuelled by populist politics demonstrates how important these forms of learning are to any humane, inclusive approach to education. We need education systems that do more than simply reinforce the status quo or reproduce patterns of domination.

A third factor that should be highlighted is Freire's emphasis on action. A key aim of education, in his view, is to support learners in practising freedom by participating in the political life of their society. Freire believed that such participation was an important part of being human. Reflection on reality must always be linked to action and agency, and education that stifled this was oppressive and 
authoritarian. We realise ourselves as human beings through collective action, and all education is a sort of dialogue about the future. There is an important message of hope in this. Education, Freire contends, takes place in a contested, political space in which the future is endlessly available to be disrupted, interrupted and remade. There is an urgent need to reframe education in terms of collective action and social change, which speaks directly to Freire and more broadly to the adult education tradition. Hope is in short supply in the world just now. Education that enables people to engage critically with the world around them and that brings with it the prospect of social change is desperately needed. It is perhaps the most important thing education can offer right now.

A number of the articles in this issue address these or related themes, and some invoke Freire directly. "Pedagogies for peacebuilding in higher education: How and why should higher education institutions get involved in teaching for peace?", by Juliet Millican, Larisa Kasumagić-Kafedžić, François Masabo and Mónica Almanza, relates the findings of an international research project on "Pedagogies for Peacebuilding". The article, which is co-authored by a team from four countries (Bosnia and Herzegovina, Rwanda, Colombia and the United Kingdom), argues that higher education institutions should take the teaching of peacebuilding, moral education and citizenship more seriously. Noting that higher education has, traditionally, "been content-focused, drawing on pre-agreed canons of knowledge delivered via a didactic approach", with "limited spaces for discussing values, ideas, beliefs, and the messiness of human responses", the authors discuss the spaces in which peacebuilding can be usefully considered within higher education curricula; the significance of higher education in helping young people develop habits of peace; and how the citizens and leaders of the future might be helped to understand the meaning and importance of peacebuilding. The authors consider the intention and impact of different pedagogical approaches, including Freire's, arguing that "The Freirean concepts of 'critical pedagogy', 'praxis' and 'pedagogy of the oppressed' (Freire 1970) have a lot to offer to the teaching and learning of conflict transformation." The authors highlight, in particular, Freire's emphasis on dialogue and equality in teacher-student interactions, the importance of local context and the limitations of "top-down knowledge transfer", noting, in conclusion, that the university has a responsibility to help its graduates hold conversations about "uncomfortable truths" and "incorporate them into their everyday practices as citizens and professionals".

The next article in this issue also places emphasis on local context, this time in the school sector. In "School-community interventions to curb learner dropout: The perceptions of key education stakeholders in a rural South African school neighbourhood", Tawanda Runhare, James Bill Ouda, Maria Tsumbedzo Vele and Ndileleni Mudzielwana examine the views of key stakeholders in South African secondary schools on strategies to curb learner dropout. The study used a qualitative case study research model, sampling secondary school learners, young people who had dropped out of school, school governing board members and teachers from two rural secondary schools engaged in tackling high dropout rates. The authors identify some of the factors responsible for dropout, including "educational practices such as assessments, exit exams, testing, and rule enforcements that students find humiliating can cause learners to drop out of school", family hardship, low teacher 
expectations and an unwelcoming school environment, and "differential treatment by race, gender, sexuality or even class", noting that the problem is particularly acute in rural South Africa. They go on to identify the main strategies used by the two schools to curb dropout, among them the National School Nutrition Programme; the "no-fee school" system; counselling on personal and family challenges; attractive extra- or co-curricular activities; encouragement of parental involvement in school matters; and collaboration between the community and school leadership in monitoring learners. The authors conclude by emphasising "the need for communities, families and education management systems to build bridges and not walls around themselves", and calling for schools and communities to work together to increase learner motivation and reduce dropout.

Our third article, "Key factors influencing the maintenance of adult learners' literacy skills levels: A follow-up study of three participant cohorts of the literacy programme in Cambodia", written by Sophat Lang, likewise reflects on the relationship between the classroom and the wider environment. It considers the literacy struggles of adults, examining the current level of literacy skills of three cohorts of learners who completed a non-formal basic literacy programme in 2017, 2018 and 2019 respectively. The author sought to identify the factors that influence the maintenance of learners' levels of reading and calculating skills, using a test instrument and a background questionnaire. While he observed no significant difference in skills levels among the three cohorts or in terms of different demographic backgrounds, such as age, gender and occupation, he found factors affecting literacy levels to include the frequency with which individuals used and practised their literacy skills, and their attitudes towards learning and skills use. Critically, the surrounding environments and contexts in which many of the learners lived did not enable them to apply their literacy skills in everyday life, thus limiting the impact of the programme. The study concludes that the quality of Cambodia's non-formal basic literacy programme needs improving, and that "non-formal follow-up programmes are required for neo-literates to strengthen their basic skills in reading, writing and calculating, and develop their work-related skills".

"Education for just transitions: Lifelong learning and the 30th anniversary Human Development Report", written by Simon McGrath and Séverine Deneulin, considers the 30th anniversary Human Development Report (HDR), entitled The Next Frontier: Human Development and the Anthropocene, released by the United Nations Development Programme in December 2020 (UNDP 2020). ${ }^{4}$ The report, the authors say, marks "a new turn in the human development journey on which the global community embarked with the publication of the first HDR in 1990", framing "a new human development narrative that sees "social and natural systems as embedded in each other' (ibid., p. 23)" and revisits "what it means to develop as human beings interconnected within earth systems". However, while the "intellectual underpinnings" of the human development school of thought can be traced to

\footnotetext{
${ }^{4}$ UNDP (United Nations Development Programme) (2020). The next frontier: Human development and the Anthropocene. Human Development Report 2020. New York: UNDP. Retrieved 29 SEptember 2021 from http://hdr.undp.org/sites/default/files/hdr2020.pdf .
} 
the influence of Paulo Freire and Ivan Illich, who framed basic needs achievement in terms of a strong lifelong learning perspective through a focus on non-formal education, the lifelong learning perspective has tended to be neglected in human development literature. The new report has the same fundamental flaw. It prioritises consideration of capabilities, agency and values as central to the human development challenge, and opens up a discussion of how we need to change our understandings, values and actions, including what it means to be human, in order to effect just transitions towards sustainability. However, it fails to consider the lifelong learning challenge inherent and central to just transitions. This is regrettable, the authors argue, since the pressing challenge of responding to the climate emergency requires a richer understanding of how humans learn throughout their life course, and the report misses an opportunity to learn from relevant literature, particularly on adult education and the role of faith communities.

The fifth article in this issue focuses on teachers. "Investigating the relationship between teachers' teaching beliefs and their affinity for lifelong learning: The mediating role of change tendencies", written by Cihad Şentürk and Gökhan Baş, investigates the mediating role of change tendencies in the relationship between teaching beliefs and teachers' lifelong learning affinity. This is important since teachers with a high affinity for lifelong learning are more open to professional development and better able to cope with problems in teaching and learning. Using three questionnaires, the research team collected responses from 288 teachers (147 female, 141 male) serving in public secondary schools in the province of Karaman, Turkey. In their analysis of the data, the team found a significant negative relationship between teachers' traditional (teacher-centred) teaching belief, change tendencies and lifelong learning affinity; whereas the relationship between a constructivist (student-centred) teaching belief, change tendencies and lifelong learning affinity turned out to be significantly positive. The results seem to indicate that change tendencies fully mediate the relationship between teaching beliefs and lifelong learning affinity. Based on these results, the authors conclude that teachers' potential openness to change - and their affinity for lifelong learning - are greater when their teaching is guided by a student-centred approach than when they take a teacher-centred perspective.

Our final article explores "Non-formal education and economic growth in Nigeria: The need for a system-wide programme development framework". Authors Dorida Nneka Oyigbo, Patrick N. C. Ngwu and Ruphina U. Nwachukwu note that the non-formal education approach to fostering human proficiency in a wide range of skills has been credited with engendering the broadening of educational practice beyond formal schooling through the emergence of methods and techniques of basic education, administrative training and management science. The article describes how, in the field of economics, the relationship between national economic growth and upskilling the population is informed by two major dominant theoretical perspectives. The "human capital" approach considers the relationship between education and national economic growth from purely economic viewpoints, while the "ecological development" approach adopts a liberal stance and argues for a democratisation of educational opportunities. After reviewing this theoretical background, the authors focus on the need to strengthen non-formal education in Nigeria with the aim of promoting national economic growth. They propose that the National Mass 
Literacy, Adult and Non-formal Education Commission, launched in 1991, should be upgraded to a ministry of non-formal education. This kind of dedicated ministry is already operating successfully in many developing Asian and industrialised nations, they note, serving to coordinate all basic education programmes with a special focus on citizens with low literacy. In Nigeria, the authors argue, such a ministry could provide training and retraining of all workers in both the public and private sectors of the economy, and facilitate administrative training and executive management education, as well as taking on responsibility for all continuing professional training programmes at all levels of the polity. They conclude their article by setting out the main elements of their proposed programme development framework for non-formal education.

The authors of this last article reference Freire as the source of the concept of conscientisation, which they find relevant in the context of "raising awareness among stakeholders on an ongoing basis". This is important since conscientisation - or the cultivation of critical consciousness - is Freire's way of showing how all education is a field of struggle over the future, a fundamentally dialogical and open-ended process premised on questions rather than answers. Education, thus conceived, gives students hope by presenting them with the means to reflect on their own experience and see the world anew through their collective reflection and action. The job of the teacher is not to pour knowledge - too often the reheated soup of received ideas - into the minds of learners; it is to initiate a dialogue, one characterised by mutual respect, empowerment and care for the future. As climate activist Greta Thunberg said in her criticism of the "blah, blah blah" of world leaders in a speech at the Youth4Climate conference: "Hope is not passive. Hope is not 'blah, blah, blah'. Hope is telling the truth. Hope is taking action. And hope always comes from the people" (Thunberg, quoted by Carrington 2021). ${ }^{5}$ In times such as these, where many millions of people around the world live lives of quiet despair, burdened and disconnected, and spaces for collaboration and dialogue are rare, such hope, elusive though it is, could not be more necessary or important. As we strive to find a way through our problems and shape a future fit for future generations, Freire's voice is still needed. We need to talk about freedom and struggle, hope and justice, and Freire gives us a language in which to do it.

Publisher's Note Springer Nature remains neutral with regard to jurisdictional claims in published maps and institutional affiliations.

\footnotetext{
5 Carrington, D. (2021). "Blah, blah, blah": Greta Thunberg lambasts leaders over climate crisis. The Guardian, 28 September [online article]. Retrieved 29 September 2021 from https://www.theguardian. com/environment/2021/sep/28/blah-greta-thunberg-leaders-climate-crisis-co2-emissions.
} 